\title{
INTERNATIONAL ECONOMIC RELATIONS AND THEIR INFLUENCE UPON POWER CENTERS EVOLUTION
}

\author{
Bogdan Simion Malanciuc \\ Bucharest University of Economic Studies \\ malanciucbs@yahoo.com
}

\begin{abstract}
The relative advantages of the nations at the top of the international hierarchy are never constant, the reasons being in particular related to the uneven rhythm of development of the various societies. This rhythm is correlated with technological and organizational advances, which offers a great advantage to certain societies in relation to others. In this context, international economic relations, any kind of exchanges between countries, have influenced the rise and fall of the world's states power. History proves that the great powers have managed to maintain their status as long as they have been in the center of the world trade.
\end{abstract}

\section{Keywords}

international relations, power center, international economics, trade

\section{JEL Classification}

$\mathrm{J} 50$

\section{Concepts of "power" and "power center"}

The importance of the power phenomenon in the development of the society is incontestable and certain. Yet, this phenomenon is insufficiently studied by economists; the most active researchers of this factor have been and are still the philosophers, the sociologists and the politologists. Literally, the power does not make part of the economy mainstream. Thus, we notice among researchers an ambiguous interpretation of power, there being different and sometimes contradictory approaches of the issue of power and its role in the economic development.

According to Robert Dahl's observations in 1957, "this word [power] and its synonyms are incorporated in all civilized languages, more often in meanings that slightly differ: power, influence, control, pouvoir, puissance, Macht, Herrschaft, Gewalt, imperium, potestas, auctoritas, potentia etc" (Dahl, 1957). Dahl sees power as being a relation between actors A and B; "A has power over B to the extent that he can get B to do something that B would not otherwise do" (Dahl, 1957). To do that (changing behavior), state - actor A should have some ways to convince state - actor B. This are the resources of power: geography, resources, population, economy, military might and so on.

Power centers are the actors A that have the biggest resources to influence others. Throughout history a number of states have managed to be considered great powers: Spain, France, Austria, Prussia (later Germany), England, Russia (Soviet Union), United States.

\section{International economic relations as a resource of power}

International economic relations can be and are seen as a resource of power of different states. 
As early as 1817 , Ricardo's comparative advantage theory demonstrated that free trade is more advantageous for all parties than the autarky. But in all historical periods there were and still are states that believe something else, some of them being great powers. Controlling exports and imports is a strategy for different power centers trying to impose their agenda on some international (or even national) issues.

Looking the other way around, is there a connection between the status of leading state of the international system (biggest power center) and the status of leader of free trade (biggest supporter of trade)?

This could be a very actual question taking into account some of the latest statements of Trump Administration: "We are not in a trade war with China, that war was lost many years ago by the foolish, or incompetent, people who represented the U.S. Now we have a Trade Deficit of $\$ 500$ Billion a year, with Intellectual Property Theft of another $\$ 300$ Billion. We cannot let this continue!" 1

\section{Power centers history and international trade}

\section{Classical antiquity}

The history of rise and fall of great powers can be analyzed since ancient times, since the Persian Empire, the Greek cities and the Roman Empire.

Of great importance for international relations is the classical period of Greek cities, around $400 \mathrm{BC}$, which exemplified some of the fundamental principles of interstate power politics (reflected in Tucidide's writings on the Peloponnesian War between Sparta and Athens). At that time, the states had sophisticated trade relations and fought each other over a wide area, from the Mediterranean to the East of Asia. According to Tucidide, the main reason for the Second Peloponnesian War was "Athens rise in power and fear that it produces in Sparta" (Nye, 2005). This rise of power of Athens was inflicted by the expansion of Greek colonies and trade (controlled by Athens' Delos League) in East Mediterranean. Athens would have become, in the eyes of former ally in war against Persian Empire - Sparta, too powerful because of this expansion. In this case, if Sparta did not intervene, international sea trade and colonization would have given birth to the first superpower - Athens.

The Roman Empire was powerful due to three reasons: language / culture, military power and commerce. Trade was one of the most important activities, roads, markets and ports being build and well maintained during the centuries. After the collapse of the Empire's might, the security of the trade routes cannot be maintained so Europe entered in the so-called Dark Age.

\section{Early modern period}

During this time in other parts of the world were different civilizations. After 1400, China under the Ming Dynasty, was a highly advanced civilization, independent of Western influences. In 1420 "Chinese fleet had 1.530 war ships, including 400 big floating fortresses and 250 vessels designed for long distance travels" (Kennedy, 2011). The most famous official voyages over the sea were the seven voyages of admiral Cheng Ho, between 1405 and 1433. They succeeded to reach Zanzibar and

1https://twitter.com/realDonaldTrump/status/981492087328792577?ref_src=twsrc\%5Etfw\&ref_url=https\% $3 \mathrm{~A} \% 2 \mathrm{~F} \% 2 \mathrm{Fwww} . \mathrm{cnbc} . \mathrm{com} \% 2 \mathrm{~F} 2018 \% 2 \mathrm{~F} 04 \% 2 \mathrm{~F} 04 \% 2 \mathrm{Fdonald}-$ trump-we-are-not-in-a-trade-war-withchina-we-lost-that-war-many-years-ago.html\&tfw_creator=thesheetztweetz\&tfw_site=CNBC 
the Red Sea with their ships (bigger than 60 years later Spanish ones). With these vessels the Chinese could easily discover Portugal some decades before European voyages, but they decided to stop. In 1436 China decided to ban the construction of maritime ships and turn the back to the international sea trade. This was one of the biggest strategic mistakes in human history, leaving an empty place that was soon occupied by the European explorers and merchants.

In Middle East, northern part of Africa and northern India were two Muslim empires, the Ottoman and the Mogul one. Their weaknesses after 1550 were strategic overdevelopment, excessive bureaucracy, conservatism, and, most important, the incompetence of leaders. Lack of new conquests and huge taxes have stifled the domestic economies, leaving no space for further positive developments in trade.

But no matter how imposing and organized these empires from other continents looked compared to the European states, they were all characterized by terrible uniformity in beliefs and practices not only in the official religion of the state but also in areas such as trade relations, education and development of new weapons.

No one would have predicted in the first part of that sixteenth century that the Europeans would impose upon others. The competition, military rivalry, between European kingdoms and city-states created the framework for military progress, scientific and technological discoveries. Turning less obstacles to progress, European societies have entered into a steady upward spiral of economic growth and improved military effectiveness that over time has raised them above all other societies from other continents.

European imperialism began in the fifteenth century with the development of vessels capable of crossing the oceans. Portugal was the pioneer of the first exploration trips. Spain, England, France and Netherlands soon followed. Through higher military technology, Europeans have gained control over coastal cities and supply outposts along major trade routes. Gradually, this control expanded deeper into the continent, first in Latin America, then in North America, and later in Asia and Africa.

In the sixteenth century, Spain and Portugal had vast empires in Central America and Brazil, and the United Kingdom and France colonies in North America and the Caribbean. The Europeans bought slaves in Africa and were transporting them to Mexico and Brazil to work in agriculture and gold and silver mines. The wealth produced was exported to Europe, where monarchs used it to maintain armies and build states.

Although continuous technological progress and ongoing military rivalry has characterized Western countries, it has always been possible for one of the competing kingdoms to manage to raise enough resources to overcome the others and thus dominate the continent. In the sixteenth century and the first half of the seventeenth century, Catholic states subjected to the Habsburg dynasty (Spain, Austria, etc.) seemed to be able to do so. Against them, virtually all other European states (confirming power balance theory) have managed to prevent them from doing so. Practically, despite the many economic resources possessed by the Habsburg kingdoms (first of all the newly discovered resources in the Americas), they did not win the war decisively. The other European states have achieved a better balance between their own material resources and their military power, managing - to the limit - to stop the domination tendencies of the Habsburgs.

The Treaty of Westphalia in 1648 established the basic rules that have since defined the international system - the sovereignty and territorial integrity of states as equal and independent members of the international system. Since then, the defeated states could be deprived of some territory, but they were generally allowed to continue as independent states instead of being embraced by victorious states. 
This period is characterized by the fierce fight in the oceans between the Catholic Spain and Portugal and Protestant England and United Provinces, plus France. Gains from international trade, resources from colonies, were used to maintain armies in Europe and paid for the bloody wars from the time. Generally, whoever succeeded to use better the resources win the long wars.

\section{Late modern period}

The conflicts between the Westphalian Peace that ended the 30-year War (1648) and the Vienna Congress that ended the Napoleonic Wars (1815) cannot be easily described as a confrontation between a certain bloc of states and its rivals. During this agitated period a few former great powers, primarily Spain, but also the Netherlands and Sweden, fell to the rank of secondary powers; other states - England (from 1707 United Kingdom), France, Prussia, Austria and Russia - dominated the politics and diplomacy of the eighteenth century, engaging in a series of coalition wars that were characterized by rapid alliances. France was the state closest to becoming the hegemon of the continent twice - first under the leadership of Louis XIV and second under Napoleon. But the efforts of the French have always been under the control of a broad coalition of the other powers.

Since the end of the eighteenth century, the maintenance of an army and a fleet has become very expensive, which has given Great Britain a great advantage, being a country that could create a more advanced manufacturing, commercial and banking system.

Table 1 Number of battleships between 1689 and 1815

\begin{tabular}{|l|r|r|r|r|r|r|}
\hline & \multicolumn{1}{|c|}{1689} & 1739 & 1756 & 1779 & 1790 & 1815 \\
\hline $\begin{array}{l}\text { England } \\
\text { (United } \\
\text { Kingdom) }\end{array}$ & 100 & 124 & 105 & 90 & 195 & 214 \\
\hline France & 120 & 50 & 70 & 63 & 81 & 80 \\
\hline Russia & - & 30 & - & 40 & 67 & 40 \\
\hline Spain & - & 34 & - & 48 & 72 & 25 \\
\hline Sweden & 40 & - & - & - & 27 & - \\
\hline $\begin{array}{l}\text { United } \\
\text { Provinces } \\
\text { (Netherlands) }\end{array}$ & 66 & 49 & - & 20 & 44 & - \\
\hline
\end{tabular}

Source: Kennedy, P. (2011), Ascensiunea și decăderea marilor puteri, Polirom Publishing House, Iaşi, p. 110

The number of ships clearly shows the huge advantage that United Kingdom had in 1815. As Prussian general Gneisenau observed in 1815 "Great Britain is the most indebted to this bastard [Napoleon]. Because, through events which he gave rise, greatness, prosperity and wealth of England increased. She is the master of the sea, neither here nor in the world trade has no rival to fear." (Kennedy, 2011).

Britain dominated world trade during this period. As Britain's economy was the most advanced in the world from an economic point of view, its products were competitive everywhere. That is why British policy favored free trade. In addition to its central role in world trade, Britain served as the financial capital of the world in the 19th century, managing an increasingly complex global market for goods and services. British currency, the pound has become the world standard. 
Another British advantage, shared with Russia, was the country's "marginal" strategic position, which allowed them to intervene in central European conflicts, yet still protected by the English Channel, respectively the huge distances from the Russian steppe.

The period of the European Concert, after the Vienna Congress, is a period almost without any conflicts, with the maximum increasing of trade. The major conflicts - the American Civil War, the Crimean War and the Franco-Prussian War - clearly showed the military superiority of the societies that had succeeded in modernizing their military forces and benefited from the industry needed to support the large armies equipped with modern weapons. There was a strategic balance, supported by all the great European powers, so that no nation was able to impose its dominance on the others. This stable international situation allowed the British Empire to expand its territory outside Europe, reaching its peak as a global power in naval, colonial and commercial terms during Queen Victoria.

In the middle of the nineteenth century, industrialization was booming, spreading from the United Kingdom to other European countries and even to other continents (British colonies, United States, Japan). The international balance of power began to shift to the new states that had the ability to use new technologies and means of production and to extract the necessary resources. It has become very important to have colonial territories - mainly for the natural resources, but also for the demographic potential offered.

At the beginning of the twentieth century the arms race, both terrestrial and naval, increased. In 1910, Germany's share of world industrial output reached 16\%, thus exceeding the United Kingdom. The economic power indices evolved year after year, showing a major change in the global balance, in the sense that the Eurocentric world system was ending. States of the size of some continents, Russia and the United States were in the forefront of overcoming the traditional European powers like France and Austria.

The industrialization of the United States economy was supported by the nineteenth century territorial expansion, which added great natural resources to it. Also, the United States economy has attracted huge masses of immigrant labor from Europe. The United States led the world in switching from coal to oil and horse-drawn carriage to the motor vehicle.

The Battles of the First World War, showed in the East a victory of national efficiency and industrial organization of Germany over Tsarist Russia, still quite backward. In the West however, mainly thanks to the economic and military aid of the United States for the countries of the Entente, Germany was decisively defeated. Although victorious, France, Italy and even the British Empire suffered more losses; Russia was embraced by the Bolshevik Revolution, leaving the United States indisputably the world's greatest power. But the Americans returned after the World War I victory to their traditional isolationism, leaving international affairs in the care of Great Britain and France. Their supremacy was questioned two decades later by the Axis powers, militarized and revisionist nations - Germany, Japan and Italy, dissatisfied with the post-World War I settlements.

Despite the fast victories of the outbreak of World War II, Germany and its allies were unable to withstand the immense imbalance in natural resources and productive capacities between them and the alliance between the United States and the Soviet Union. World War II brought the irremediable weakening of the position of France and Great Britain, though victorious, as well as of Germany defeated and divided into two states. 
British Empire, ruler of the sea until now, was replaced in the world scene by former colony United States whose Navy will ensure president Woodrow Wilson's “freedom of the sea".

\section{Contemporary history}

After the war, in 1945, the military balance again correlated with the global distribution of economic resources, defending a bipolar world from an ideological, economic and military point of view. The position of the United States and the Soviet Union as super-powers, of a separate class, was also underlined by the development of nuclear weapons, which made the diplomatic and strategic landscape differ a lot from the previous ones. Yet the growth and decline of great powers continued through differentiation of rates of economic growth and scientific and technical progress that may cause mutations in the global economy and, obviously, in military capabilities.

United States and Soviet Union have started and maintained an unprecedented race of arms, in which no other power has been able to enroll. This permanent arms race had two negative consequences on capitalist economies. On the one hand, the special importance given to the military factor (large allocations of resources) contributed to a decrease in the productivity of the economy, and on the other hand, these resources required a permanent increase of the money supply in circulation, which generated inflation and the impossibility of maintaining the exchange rate between dollar and gold.

From a military point of view, the two great powers have undoubtedly dominated the international landscape since the mid-twentieth century. From an economic point of view, the rapid return of other states, whether victorious or defeated in the last world war, has given rise to a multipolar world. Europe has quickly recovered (and with the help of the United States through the Marshall Plan), becoming the European Economic Community - the world's largest trading entity. Japan, hit by two US nuclear bombs at the end of the war, grew from a technological and economic point of view very quickly, surpassing Soviet Union in the eighties (impressive for a country practically without its own natural resources). China has progressed at a steady pace, placing a strong emphasis on the rapid industrialization of the country. Later, India and Brazil followed China's example, trying to increase their share of the global economy.

There have been three major changes that have led to the creation of a favorable context for the ending of the Cold War. These are in the view of Odd Arne Westad (Westad \& Leffler, 2010):

- the spread of the right to vote, which has led to the expansion of political participation of citizens and the formation of representative democratic institutions;

- the expansion of the capitalist world, accompanied by the move of major production centers from Western Europe to North America and then to Asia;

- the end of colonialism that led from 1945 to 1975 to creation of over 75 new independent states, which had a major impact on international relations.

There is currently only one integrated world economy and no country can remain isolated. At the same time, the imperfections and problems of the world economy are evident due to the periodic crises and the recessions of recent years. The emergence of a global capitalist economy has deepened the disparities between the richest and the poorest regions. While the United States enjoyed unprecedented prosperity, rising poverty in Africa has created a human catastrophe on a continental scale. 


\section{Conclusions}

If we analyze historical evidence of the rise and fall of great powers over the centuries, we will be able to issue some valid conclusions, although there may be some exceptions. For example, the causal relationship between the changes that have occurred over time in the overall economic equilibrium (exploitation of resources, industrialization, technology, productivity) and the place occupied in the hierarchy of national powers in the international system can be observed. The movement of trade flows from the Mediterranean Sea to the Atlantic Ocean since the sixteenth century, the redistribution of Western European industrial production to the United States at the end of the nineteenth century, has prompted the rise of new great powers. That is why we must seriously treat the shift of global productive balances to the Pacific Ocean.

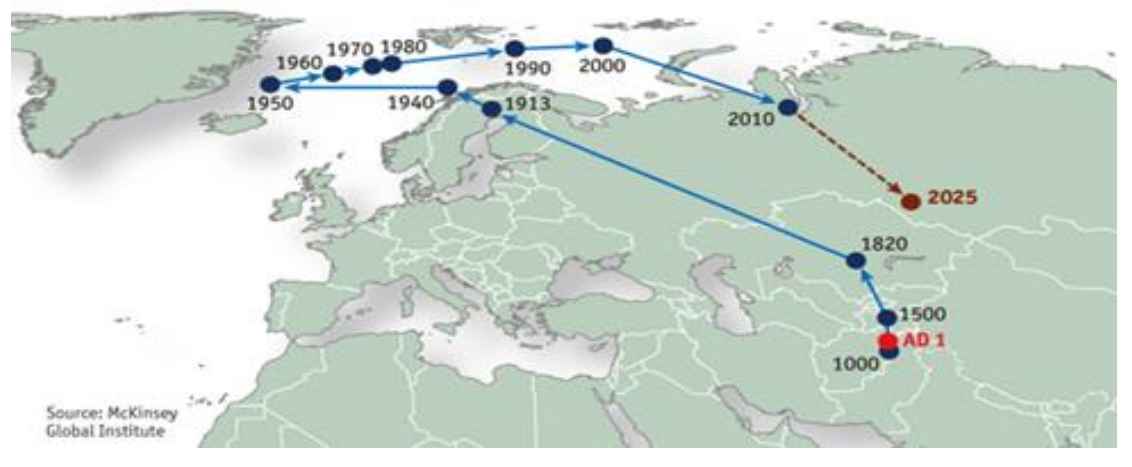

Figure 1 Evolution of the Earth's economic center of gravity

Source: McKinsey Institute (2012), Urban world: Cities and the rise of the consuming class, available at http://www.mckinsey.com/insights/urbanization/urban_world_cities_and_the_rise_of_the_consuming_clas $\mathrm{S}$

There is a very strong correlation between the results of the major wars, the coalition (Napoleonic, the two World Wars) and the amount of productive resources mobilized by the belligerent parties.

Similarly, history shows us quite clearly that in the long run there is a strong link between the rise / fall of a national economy and the increase / decrease of the military power of that state. This is normal as long as a great cost is required to sustain an impressive military force. Also, wealth and power are relative in time; it is true that Great Britain now has more powerful weapons than at the beginning of the nineteenth century and is much richer in absolute terms but its share of world production has fallen from $25 \%$ to just $3 \%$. This does not mean that the economic and military power will increase / decrease at the same speed. All history proves a notable delay between the trajectory of the relative economic power of a state and that of its military influence; The British Empire in the mid-nineteenth century, the United States at the beginning of the twentieth century, Japan in 1980, the European Union after 2000, the current China - may prefer to richer (raise living standards) than to spend money on arms. In the case of Great Britain and the United States priorities have changed half a century later. In the case of Japan, European countries, and especially China, we will see ... As the economic expansion of the first two has involved various external obligations - market dependencies, dependence on natural resources, alliances - it is possible that the development of the latter leads them towards the same results. 
Or the "lost decade" of Japan and Europe's deep economic crisis after 2007 to stop them from following the same path.

During all history the great power that dominates the international system is a supporter of trade and open commerce with the others. That is true even in mercantilist era. Great Britain and United States after World War I are good examples of such a power centers. On the other hand, we can observe that the falling powers are the ones that have the tendency to oppose relations with others, being too conservative. Ming' China, Japan before Meiji reforms, Ottoman Empire, Spain at the middle of seventeenth century are examples.

How will be a world where United States is putting customs and China is supporting free trade?

\section{References}

Goldstein, J., Pevehouse, J. (2008), Relații internaționale, București, Polirom Publishing House.

Kennedy, P. (2011), Ascensiunea și decăderea marilor puteri, București, Polirom Publishing House.

Nye, J. (2005), Descifrarea conflictelor internaționale, București, Antet Publishing House.

Westad, O.A., Leffler, M. (2010), The Cambridge History of the Cold War, volume III, Cambridge University Press.

Dahl, R. (1957), The concept of power, Behavorial Sciences, 2:3, pp.201-215.

Dobbs, R., Remes, J., Manyika, J., Roxburg, C., Smit, S., Schaer, F. (2012), McKinsey Global Institute Report, Urban world: cities and the rise of the consuming class, available at https://www.mckinsey.com/globalthemes/urbanization/urban-world-cities-and-the-rise-of-the-consuming-class 